\title{
Governance, Regulations, Trade Openness and FDI Inflows: Empirical Study
}

\author{
Marwan Ahmad Alshammari ${ }^{1,2}$, Mosab Amjad Hammoudeh ${ }^{1} \&$ Milos Pavlovic $^{3}$ \\ ${ }^{1}$ University of Texas at Arlington, USA \\ ${ }^{2}$ The Hashemite University, Jordan \\ ${ }^{3}$ Indiana State University, USA \\ Correspondence: Marwan Ahmad Alshammari, University of Texas at Arlington, USA. E-mail: \\ marwan.al-shammari@mavs.uta.edu
}

Received: August 1, 2015

doi:10.5539/ijef.v7n12p44
Accepted: November 3, $2015 \quad$ Online Published: November 25, 2015

URL: http://dx.doi.org/10.5539/ijef.v7n12p44

\begin{abstract}
Governance effectiveness and regulation quality have been drawing the attention in the international business arena, yet, there has not been a consensus findings regarding its potential impact on the FDI inflows. In this paper, we examine the possible links between the governments' effectiveness and their regulation quality and the amount of FDI inflows using the existing literature and theories in the economic and international business fields. We find that regulation quality, control of corruption, and trade openness have mixed results, suggesting that further exploration is needed in this field. Results are explained and future directions are suggested based upon the empirical findings.
\end{abstract}

Keywords: foreign direct investment inflows, regulation quality, government effectiveness

\section{Introduction}

It is commonly claimed that countries diverge in their economic performance, and that this variance among countries is attributed to multiple socio-economic factors. These factors can be political, institutional, international, as well as historical and regional factors. The variability among countries in their economic performance is argued to have an influence also on the country attractiveness of FDI (Foreign Direct Investment) (OECD, 2001). The differences between governments and their political systems, as well as the each country's level of development that reflects its human capital and also the sufficiency of its infrastructure can, to large extent, determine its attractiveness with regard to investment macroclimate. Several scholars have attributed the variations in FDI inflows to the differences between countries in these factors, political, institutional, and infrastructure factors (Hall \& Jones, 1999; Humphrey, 1998; Russett, 1968; Wheeler \& Mody, 1992).

Lucas (1990) was among early scholars to argue that the mismatch between poor and rich countries lead to little FDI inflows to the poor countries from rich countries, and contended that this holds until a certain amount of match exists. Lucas argues also that poor hosting countries may try to maximize their benefits by maximizing the taxation, thus FDI inflows are to be relatively small in comparison to other well-developed countries that have more openness and relaxed taxation policies.

There has been huge effort from scholars in several disciplines, including economics, strategy, sociology, and other interdisciplinary fields that focuses on the details that determine the extent to which the overall country's position would attract or deter FDI. It is the purpose of our paper to study some of these factors and see whether country-level differences in political stability and absence of violence, trade openness, as well as control of corruption and regulation quality have any impact on the FDI inflows.

Intercountry differences has become an important topic when addressing the FDI inflows and outflows. In fact, a decent body of knowledge in the international business arena has been dedicated to such construct. (Kobrin, 1976) conducted a study that explores the relationship between foreign direct investment (FDI) and the economic, social, and political aspects of the environment and found significant relationship between these variables. Researchers have not come across a consensus regarding the direction of the relationship between GDP for instance and the FDI. Morisset (2000) found a nearly perfect positive correlation between hosting country GDP and FDI. (Morisset, 2000). FDI in Africa: policies also matter. Transnational Corporations, 9(2), 107-126). 
Peterson et al. (1999) found that this isn't necessarily true and doesn't hold across countries. Furthermore, the author argues that this correlation may not be the case if the country has several other attractive factors to make up for the short on resources.

Government policies are meant to establish the appropriate grounds for economic growth and prosperity. These policies however are highly influenced by the overall political system, history, human capital traits, resources, international community recognition, country activism, and many other related factors (Globerman \& Shapiro, 1999; Habib \& Zurawicki, 2002; Sahoo, Nataraj, Dash, \& Ebooks Corporation, 2014). Human development, political systems efficiency and effectiveness are both related as the purpose of the latter is solely dedicated, or at least said so, to serve the former. Countries that have established decent systems that are flexible, democratic, corruption-clean, and respectable and applied laws and investment attraction policies would be more likely a target of foreign investment as a potential of success seems to exist (Morisset, 2000; Humphrey, 1998). (Humphrey, J., \& Schmitz, H. (1998). Trust and inter-firm relations in developing and transition economies. Journal of Developing Studies, 34(4), 32-61).

Variables that represent the country attractiveness have been used in several studies in the international business arena, as well as the economic and political economics arenas. These variables are well-established by several international organizations that either a subdivision of the $\mathrm{UN}$ or independently functioning at the international level. The World Bank, International Monetary Fund, United Nation and some other organizations have been a great source of data in this regard.

The decision of where to locate a new investment is a difficult and crucial one. Multinational enterprises make extensive studies before they decide whether or not to enter a country. Several factors come into play as decision makers evaluate their options. Such factors, including and not limited to infrastructure development, regulations, laws, availability of well-equipped human capital are of high importance. (Hall \& Jones, 1999; Siddharthan \& Lakhera, 2005; Wheeler \& Mody, 1992) have found support for the infrastructure, political system efficiency. However, these scholars, among others, did not find consensus results regarding the administrative norms, corruption, and some other controls issues.

Allen and Aldred (2013) studied the regulatory and institutions' quality effect on both FDI inflows and economic growth in the Eastern European countries that had joined the EU recently. Their research showed that some of these countries have been able to attract FDI and to post strong economic growth, despite the relatively higher costs associated with doing business in these countries. (Allen \& Aldred, 2013). Thus, suggesting other factors such as the easiness of doing business, resources, stability, and other relative factors that typically affect the FDI inflows.

The purpose of this paper is to re-examine these relationships between country-level factors and the foreign direct investment inflows. The paper tries to shed light on the importance of regulations' quality, political stability, control of corruption, and more importantly trade openness. The study also sheds light on the moderation effect of regulation quality in countries that have the same levels of openness. This paper contributes to the literature by 1. Extending support for the positive role of trade openness with respect to FDI inflows 2 . Separately examines the individual effects of control of corruption, quality of regulation, political stability on the FDI inflows 3. Testing the moderation effect of regulation quality on the relationship between openness and FDI inflows.

\section{Literature Review and Hypotheses}

Determinants of FDI is one of the controversial issues in the economic and strategy literature. Some scholars have argued that country regulation, business cost, political stability, human capital, and some other related factors are important determinant and attractors for FDI (Globerman \& Shapiro, 2002). However, others have argued that these results are not robust, and thus there are factors such as cultural distance factors, trade agreements, and relative labor endowment (Blonigen \& Piger, 2014). Blonigen and Piger found little support to factors that are related to host country infrastructure and host country institutions.

FDI is said to have a huge effect on hosting countries in terms of economic growth and development. Scholars have found support to the positive effect that FDI inflows have had on countries where they have been invested. (Khawar, 2005) argues that FDI inflows have huge and positive impact on hosting countries, even larger than the domestic investment. She argues that FDI inflows is indeed positively related to the GNP per capita. However, a direction of causation has not been established and scholars have recognized this in their scholarly work, and so did Khawar (2005).

The magnitude of foreign direct investment effect is said to vary across countries. This is reasonable as the 
impact for example on an underdeveloped or still developing country would be expected larger when more FDI is invested and capitalized in the country, whereas it is not expected to add much for already developed country when compared to the former. Herzer (2012) argues that the effect of FDI varies across countries, and that this variation is mainly explained by cross -country differences in freedom from government intervention, business freedom, and export dependence (Herzer, 2012). Therefore, it is obviously arguable whether FDI inflows is the same across countries.

Corruption for instance, has been argued to have a negative impact on the country attractiveness of FDI (Melo \& Quinn, 2015). Corruption is a function also of several other factors that facilitate it and makes it possible. In countries where the role of law is strong and present, we would not expect the same level of corruption to exist at the same rate for countries with very little role for law. The quality of the country and its attractiveness would be negatively affected by the levels of corruption, as investors and MNCs would not be willing to risk their money and invest in countries where corruption is at high levels. Melo and Quinn (2015) argue that corruption has a negative impact on attracting foreign direct investment but this is mitigated based on the amount of oil the receiving country produces. Foreign direct investment inflows are found to reduce corruption in countries, but not if the receiving country is a major oil producer. Results show that poor countries without oil may be using institutional corruption to attract foreign direct investment and that receiving these investments is reinforcing this corruption. (Melo \& Quinn, 2015).

The FDI and economic growth literature has long focused on the role of governments' effectiveness in attracting FDI, and in establishing promising grounds for foreign investors and firms. The political rational and sole duty of governments is ensuring that their countries stand competitive in being a desired destination for MNCs. Lee (2005) argues that national policies regarding treatment of foreign investment isn't necessarily a good and significant explanatory determinant of variation in FDI inflows across countries. Furthermore, Lee suggests that regulatory policy, as well as treatment of FDI policies are robust to some conditioning variables that are outside the control of national (Lee, 2005). On the contrary, Globerman and Shapiro (2002, 2003) studied the relationship between governance infrastructure-which captures in its measure regulatory quality as well as other variables such as effectiveness, control of corruption- and found that countries that fail to achieve a decent threshold of effective governance are unlikely to be a potential for inward FDI, especially a US-Based FDI. Furthermore, countries that have typically less transparent markets and ineffective governments, and weak legal systems are less likely to be a target for a U.S based investment. The authors also find support for the notion that these governmental-controlled variables are important determinants of the amount of the FDI received by a country (Globerman \& Shapiro, 2002; Globerman \& Shapiro, 2003).

The legal systems of different governments are typically manifested in an institutional environment and regulatory quality of the country with respect to overall effectiveness of law and regulations. These systems differ based upon the level off democracy, economic status, social status, and several other historical and geographical, as well as geo-political factors. Siegel et al. (2013) studied the effect of cultural distance using cross-country differences and how organizations (MNCs) respond to such inequalities in terms of cultural systems, as well as other features of the prevailing legal and regulatory systems and economic developments in their decisions of selection of their international expansion and international investments locations. The authors argue that a set of competing accounts influence such decisions, including cultural factors, legal and regulatory factors, and institutional factors. Furthermore, they find support to their argument that egalitarianism is related with some organizational practices in a conceptually compatible way with an array of organizational practices that are influenced by the firms' interactions with national differences, and that these interactions and differences do affect firms' decisions of international expansions, thus are considered FDI determinants (Siegel, Licht, \& Schwartz, 2013).

Yeaple (2003) argues that the MNCs' behavior with respect to international investment is not well explained by the existing models of FDI. The author states that some MNCs adopt a vertical integration strategy in certain countries, and follow a horizontal integration strategies in other countries. Furthermore, the author finds that falling transportation costs would enhance the likelihood of adopting complex integration strategy, also known as horizontal integration strategy. The author finds that complex strategy is sought as to find complementarities between hosting countries, and that these complementarities have crucial implications for the FDI structure (Yeaple, 2003). However, whether the transportation costs is due to country level factors or other factors is not explained. It is noteworthy to examine whether country governance effectiveness helps attracting FDI and establishing promising ground for MNCs to enter these countries.

The causal direction between FDI inflows and economic development and growth is also another controversial issue. While one might argue that FDI inflows should improve the overall economic performance of a country 
through employment opportunities and enhanced GDP; others might argue that consensus findings have not been found across different studies. (Ram \& Zhang, 2002) argue that cross-country studies that address the role of FDI is significantly better than single-country studies. The authors find that FDI does play a role in improving economic performance and growth in countries where the environment is encouraging and politically stable (Ram \& Zhang, 2002).

In this paper, we focus on cross-country differences effect on the country's attractiveness of foreign direct investment. we argue that FDI inflows will be influenced by several socio-economic variables, such as the political stability, government effectiveness, and role of law, regulatory quality, and control of corruption. These measured have been recently become popular in measuring country's overall attractiveness for foreign investment. We also include human-capital related factors as suggested by Globerman and Shapiro (2003) to test whether the human capital capabilities (such as education and well-being) play a role in FDI inflows across and between countries.

\subsection{Trade Openness and FDI Inflows}

(Liargovas \& Skandalis, 2012) argue that trade openness plays a positive and significant role in attracting FDI inflows. The authors studied this relationship in the context of developing countries, selecting only those countries that are considered developed under the categorization of the united nation. The authors however, claim that they find a direct causality between FDI inflows and trade openness and that openness leads to foreign direct investment inflows. we also argue that trade openness does play a positive role in attracting FDI, but we don't aim at establishing direct causality as we believe a causality in such context is difficult to establish for many reasons, including the sample selected which only contain countries that are categorized as developing and not underdeveloped, which creates a sample bias, as well as other country specific factors such as raw materials, infrastructure, transportation costs, the distance between the country and the central global markets.

Kim, Lin, and Suen (2013) studied the relationships between FDI as an explanatory variable and its impact on the level of development in countries with high level of corruption and low trade openness. The authors also studied the relationship between trade openness and investment regulations and FDI and found a positive relationship between trade openness and FDI. It should be noted that the authors found that FDI positive impact on a country economic growth is more for countries with low human capital and negative on countries that have higher levels of human capital measured by HDI (Human Development Index), suggesting that the effect of FDI is higher for less developed countries.

Trade openness would enable foreign investors from freely entering the country, establishing their businesses without fearing the protectionism, competing locally against local competitors, and also exercise their voice with the local governments. Thus, it is expected that countries with higher levels of trade openness are more likely to receive FDI inflows than countries with lower levels of trade openness and more trade restrictions.

Shirazi et al. (2010) studied the relationship between trade openness and foreign direct investment and found general positive effect for openness on the flows of foreign direct investment in the Asian countries. Constant, (2010) found similar results that indicated a positive effect of openness on foreign direct investment in the African countries. Cuadros et al. (2004) also found support for the positive relationship between openness and FDI inflows for the Latin American countries.

Hypothesis 1: The FDI inflows will be positively related to the trade openness, so that the higher the trade openness score of a country, the larger the amount of the FDI inflows for that country.

\subsection{Political Stability}

It is commonly argued in the economic literature that the country economic progress and growth is, to large extent, determined by its political system effectiveness, transparency, democracy, and regulation quality (Globerman \& Shapiro, 2003). The international business literature have commonly referred to the country specific factors that either attract or expel the FDI inflows as country risk factors, including its political system stability and violence (Keefer \& Knack, 1997).

It is reasonable that MNCs would be willing to invest in a relatively stable countries than risking their capital in a turbulent countries where systems don't function properly and would create multiple hurdles for investors. The international business scholars have widely used country specific factors in their studies of FDI (Allen \& Aldred, 2013; Habib \& Zurawicki, 2002; Torriti \& Ikpe, 2015a). In this paper, we use measures that have been utilized to measure the countries overall attractiveness in certain dimensions. These measures are developed by the World Bank in cooperation with several international organizations, the measures are discussed further in the measurement section. 
The notion here is that political stability facilitates the progress of a country. It enables governments from putting their plans in place, implementing them, and improve country's infrastructures. Political stability also enables governments from establishing a calm and encouraging atmosphere where all major constituents engage in the political process and in setting strategies that aim at developing the country. Thus, political stability can play significant role in pushing forwards the economic development of a country.

Kim (2010) studied the relationship between FDI inwards and political stability, as well as the level of corruption. Interestingly, he found a positive relationship between corruption and FDI inflows, indicating that countries where governments have higher levels of corruption are more likely to receive FDI than countries with lower levels of corruption. This could be due to the fact that these foreign companies may prefer to invest in countries where they could receive preferential treatment. However, this stands at odd with what Kaufmann et al. (2002) have argued that corruption is negatively related to FDI inflows, as well as the findings of Globerman and Shapiro (2003) that corruption harms countries and therefore play negative role in the overall evaluation of a country's governance infrastructure, thus lead to lower levels of FDI inflows. Kim (2010) also argues that political stability, which he measured by the political rights, have negative relationship with FDI inflows. Therefore, it is noteworthy to revisit these relationships and test whether FDI inflows is affected somehow by corruption and political stability. Taking into consideration that the measures here are quite different than what Kim (2010) in constructing the political stability variable.

However, economists across the world have argued that political stability is a key in ensuring the country's attractiveness for FDI. In a series of papers, Kaufmann and colleagues argue that countries that aim at improving the level of foreign investment need to consider stability, violence, corruption and infrastructure in order for these countries to have a better chance in attracting FDI in today's highly competitive and global business environment.

We extend this argument and argue that political stability plays a role in improving the country's chances of receiving FDI. Political stability is a key to improved infrastructure, less violent environment, and also play a role in improving the country's orientation towards better and advanced education that would lead to better equipped human capital, which is a key in attracting FDI inflows as Golberman and Shapiro argue.

Hypothesis 2: FDI inflows will be positively related to the level of political stability and absence of violence. That is, the higher the level of stability and absence of violence, the larger the amount of FDI inflows into the country.

\subsection{Corruption and FDI}

Corruption is the abuse of public authority and discretion for private gain (Ardiyanto, 2012). Corruption has long been studied in the economic literature, political economy, and the international business literature (Bénassy-Quére, Coupet, \& Mayer, 2007; Habib \& Zurawicki, 2002; D. Kim et al., 2013; H. Kim, 2010; Melo \& Quinn, 2015). Scholars from these fileds have tried to link corruption to several macro-economic level variables, as well as micro-level variables. For instance, Kim et al., found that countries with higher levels of corruption receives larger amount of foreign direct investment. Melo and Quinn found similar results in the context of oil countries. On the contrary, Habib and Zurawicki (2002) found a negative relationship between corruption and FDI inflows.

Corruption is generally seen as harmful to investment in that it would cost more for doing business in corrupt countries. However, according to the efficient grease argument corruption might be beneficial as it could speed up the process of establishing businesses through bribes (Méon \& Weill, 2010).

(Ardiyanto, 2012) found that corruption is indeed beneficial for countries that are still developing. It attracts foreign direct investment at faster pace and larger scale than it does in advanced countries.

Bellos and Subasat (2012) argue that corruption is not negative in the case of FDI. The authors tested the relationship between corruption levels and FDI in 15 countries and used a panel gravity model to test the effect of corruption, if any, on the amount of FDI. The findings suggest that corruption actually does not negatively affect FDI inflows, and it is mostly positively associated with FDI inwards (Bellos \& Subasat, 2012). (Zurawicki \& Habib, 2010) acknowledge that Over 25 years of research on corruption and its economic implications, including the FDI inflows yielded interesting, yet conflicting results and suggest that corruption does not cause a constant negative impact upon FDI, regardless of circumstances. Suggesting that there is a need for further research in this context.

Tentatively, corruption can function either as an impeder by causing uncertainty, operational inefficiencies, and transaction costs, which should hinder FDI inflows or as an aid based upon the grease money argument, which in 
turn facilitate commerce and business for foreign investors in corrupt countries (Quazi, 2014). Quazi (2014) found that corruption has a negative and significant impact on the levels of FDI inflows in East Asian countries. However, it should be noted that capital labor costs and raw materials may have affected the results, which may be one of our intentions to further investigate such effects in future studies for the Middle-Eastern countries, as well as African countries (Quazi, 2014).

(Kaufmann \& Wei, 1999) studied the relationship between corruption and foreign investment extensively in a series of studies. The authors used data from three global firm-level surveys to test the relationship between bribe payment, management time wasted with bureaucrats, and cost of capital. The findings were opposing the efficient grease money perspective. Furthermore, Kaufmann \& Wei found that firms that pay more bribes in corrupt countries to facilitate their business affairs have spent more time negotiating the regulations of their business, and also endured higher cost of capital. Similar to the findings of Kaufmann and Wei were the findings of Habib and colleagues (2002), where they report a negative relationship between the level of corruption in the host country and the amount of FDI inward. Habib and his colleagues found that foreign investors mostly evade countries where corruption is prevailing phenomena as it creates operational inefficiencies.

Overall, there are two streams that suggest conflicting results and opposing relationships. In this study, however, We argue that corruption is more likely to have a negative impact on the country attractiveness for foreign investments, based upon several arguments provided by Kaufmann et al., 2003 and 2003 studies, as well as Habib and colleagues (2002).

Hypothesis 3: The FDI inflows will be negatively related to the level of corruption in countries.

\subsection{Regulation's Quality and FDI}

Business regulations, also known as investment regulations, have been recently an important consideration in the international business literature. Governments in most world countries are trying to improve their business legislations to promote investment in their countries and encourage foreign investors to come and invest in their countries. In a recent study, Torriti and Ikpe (2015) studied the relationship between the quality of regulations applied by countries related to foreign investments and the FDI inflows. The authors found that regulations that facilitate and encourage investors, less protectionist, less bureaucratic, and with no complications have a huge positive and significant impact on the foregn direct investment inflows (Torriti \& Ikpe, 2015b). similar to these findings, (Wu, Li, \& Selover, 2012a) found that countries where the quality of regulations is high and the rule of law is present experience higher levels of FDI inflows, where countries that have weaker regulations and more loose and vague regulations have lower amount of FDI inflows.

The argument is that foreign investors would most likely prefer dealings that can be transparent, well-clarified, and well-stated in regulations. They also prefer regulations that don't impede the speed of their business establishments or offer some sort of protectionism against foreign investors. Thus, firms would prefer countries that have regulations with investment promotion codes and have higher quality in terms of establishment, registration, and initiation regulations, as well as operational and environmental regulations.

Hypothesis 4: FDI inflows will be positively related to the quality of regulations in countries.

\subsection{Moderating Role of Regulation Quality}

In the last decade, advanced, developing, and under-developed countries have experienced a huge increase in the number of their investment-promotion initiatives that were aimed at improving the countries' attractiveness of FDI, as well as reducing the administrative costs that are usually associated with business establishment in their countries (Torriti \& Ikpe, 2015a).

In most developed countries, regulations are assumingly way better than regulations in underdeveloped and developing countries, which is largely due to the institutional effect as these advanced countries enjoy the benefits of democracy, freedom, transparency and other historical factors. Bénassy-Quére et al. (2007) study the effect of regulations quality and institutions across countries on the level of FDI inflows. The author reported significant effect of regulations on the level of FDI inflows even between most developed countries. The author finds that a wide range of factors, including bureaucracy, corruption, and more importantly legal institutions that regulate trade, do have significant impact on the FDI inflows.

That said, it is noteworthy to search for what differentiates between countries that have the same level of openness towards foreign trade and investment. That is, what if two countries in the same geographical territory have the same level of trade openness due to their membership for example in a regional trade agreements, but they do have some differences in their regulations with respect to business establishments and related procedures (Bénassy-Quére et al., 2007). 
Countries strive for FDI inflows as it is among the major economic driver for economic growth (Globerman \& Shapiro, 2003). They compete for FDI by establishing regulations that would increase the country attractiveness for FDI inflows with the prospect of relatively lower operational costs (Pandya, 2008). However, as Pandya (2008) put it "governments often restrict FDI inflows into their countries, sometimes quite extensively" by imposing some restrictions and increase tariff. Thus, governments do vary in their perspective towards FDI inflows and this variation, in part, due to some protectionism policies adopted to protect domestic investors and businesses. Not all countries, even the most developed, however have the same regulations when it comes to FDI inflows, and therefore the trade openness level would not be a sole factor of determining the level and the magnitude of FDI inflows. In fact, it is reasonable to argue that when everything is being held constant, we would expect that countries with better regulations that facilitate trade, foreign investments, and impose fewer restrictions to attract more FDI than countries that don't have the same attributes, even if they both are considerably open for trade at the large scale (Pandya, 2008).

Hypothesis 5: Regulation quality will positively moderate the relationship between trade openness and FDI inflows. Such that, countries with high levels of openness and higher levels of regulation quality will receive more FDI inflows than countries with the same level of openness but lower levels of regulation quality.

\section{Sample, Data, and Measurement}

Because of the differing measures used in the literature to operationalize countries' specific socio-economic and political, as well as legal systems related factors, We follow the measurement used by Globermann and Shapiro (2002, 2003), Kaufmann (2002) and Kaufmann et al. (2003) and several other scholars who use the data published by the world bank on countries all around the world to measure country-level variables.

We use the database of the World Bank where multiple indices are published. The World Bank develops these data in cooperation with governments' agencies, NGOs, and economists.

The year for which the data was selected is 2012. We selected 2012 as it represents most recent period of time in which we found few studies used such recent time cross-sectional data. Also the availability of the data limited our choice.

The initial sample comprised of 75 countries that were randomly selected from all continents. The selected countries have to represent different levels of economic development. Therefore, wemanually made sure that the countries selected in the initial sample were diversified in that regard. After checking the sample, we found many missing data points, especially for some of the underdeveloped countries. We decided to eliminate the countries with multiple missing values.

The final sample comprised of 59 countries. Of which, almost $20 \%$ were advanced, 35 were developing, and $45 \%$ were under-developed based on their GDP, R\&D Productivity for which we used the scientific number of publication, as well as the public spending on education as proxies, and based on other commonly used measures for categorizing countries into developed, developing, and under-developed.

In the course of the analysis, any other missing data were dealt with using the commonly used technique in SPSS which is a list wise deletion.

The World Bank publishes annual data on countries, these data range from life expectancy at birth to all economic and political factors. The data uses scale measurements based upon the information that the World Bank obtain from agents and sub-units in all countries.

\subsection{Dependent Variable}

(FDI Inflows): Foreign direct investment are the net inflows of investment to acquire a lasting management interest (10 percent or more of voting stock) in an enterprise operating in an economy other than that of the investor. It is the sum of equity capital, reinvestment of earnings, other long-term capital, and short-term capital as shown in the balance of payments. (World Bank Definition). Since the FDI inflows are measured in millions of dollars, and for distribution purpose, we transformed the variable FDI into the natural logarithm and is therefore referred to as LnFDI on this paper. The purpose of transformation was to get a normal distribution for the variable FDI inflows.

\subsection{Independent Variables}

Control of Corruption: Estimated value for the control of Corruption that captures observations of the extent to which public power is exercised for private gain. Estimated value gives the country's score on the aggregate indicator that ranges from approximately -2.5 to 2.5 . (Kaufmann et al., 2010)

Detailed documentation of the WGI, interactive tools for exploring the data, and full access to the underlying 
source data available at www.govindicators.org. The WGI are produced by Daniel Kaufmann (Brookings Institution), Aart Kraay (World Bank Development Research Group) and Massimo Mastruzzi (World Bank Institute).

Political Stability and Absence of Violence/Terrorism: Estimated value of Political Stability and Absence of Violence/Terrorism captures the perceptions of the likelihood that the government will be destabilized or overthrown by unconstitutional or violent means, including politically-motivated violence and terrorism. Estimate gives the country's score on the aggregate indicator, in units of a standard normal distribution, i.e. ranging from approximately -2.5 to 2.5 . (Kaufmann et al., 2010)

Regulatory Quality: Estimated value of Regulatory Quality captures perceptions of the ability of the government to formulate and implement sound policies and regulations that permit and promote private sector development. Estimate gives the country's score on the aggregate indicator, in units of a standard normal distribution, i.e. ranging from approximately -2.5 to 2.5 . (Kaufmann et al., 2010)

Trade openness: Is a scaled measure developed by the World Bank in cooperation with several organizations and scholars including Brooking institute, Kaufmann and colleagues. The measure is scaled from 1-6 (where 1 indicates a very week and 6 indicates most open for international trade country).

\section{Methodology}

Since we have obtained several country-specific variables, we decided to run factor analysis using the Principle Axis Factoring with direct Oblimin Rotation to see if there is a possibility that the items hang together, thus we can aggregate a measure for country governance infrastructure. However, after running the Factor Analysis, the analysis yielded three factors with a total variance explained of $80 \%$. Two criterion were applied to extract factors, the Eigenvalue criterion which would extract any factor that has a value greater than 1 and the Scree Plot. We also set a cut-off value to suppress any items that has a loading smaller than 0.45 . The items were loaded as follows:

\begin{tabular}{lccc}
\hline Pattern Matrix & \multicolumn{3}{c}{ Factor } \\
\hline Items & 1 & 2 & 3 \\
& 0.856 & & \\
Gnp_Per_Capita & 0.815 & & \\
Healthexp_Per_Capita & & 0.671 & \\
Rdpub & & & \\
Pseduc & & 0.769 & \\
Air Transport, Registered Carrier Departures Worldwide & & & \\
Secschol & 0.656 \\
Tradeopenness 1-6 (1 Very Week And 6 Most Open & 0.987 & & \\
Corrupt & 0.887 & & \\
Goveffec & 0.84 & & \\
Politstb & 0.742 & & \\
Regqualt & 0.93 & & \\
Law & & & \\
Countstr & 0.19 & 0.2 & \\
Reliability & & & \\
\hline Rotation Method: Oblimin With Kaiser Normalization. & & \\
A Rotation Converged In 9 Iterations. &
\end{tabular}




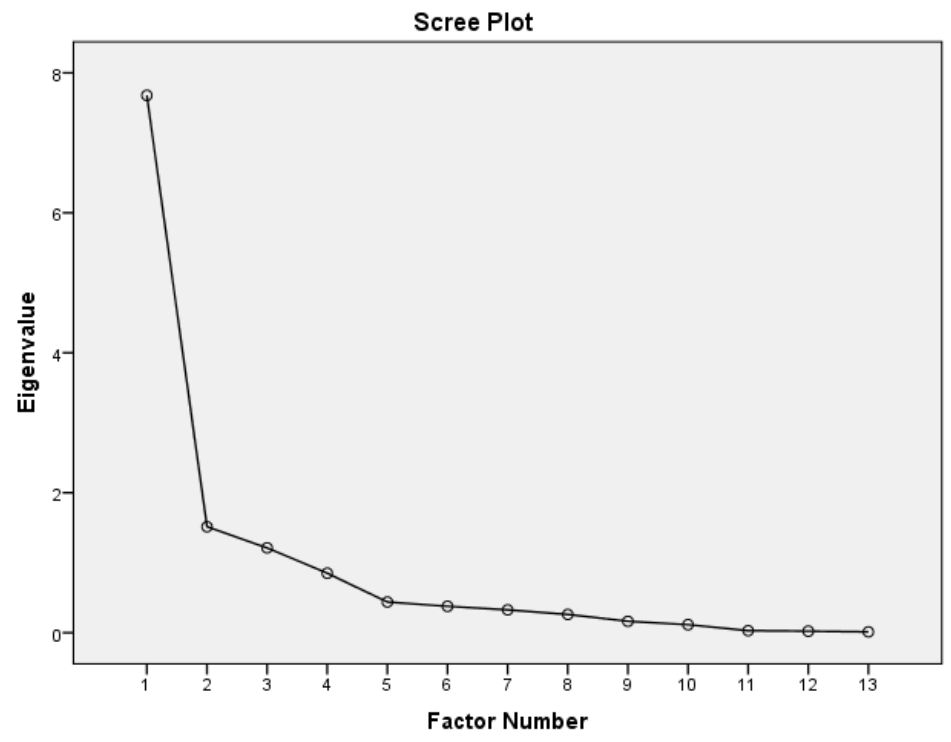

Figure 1. Scree plot output from factor analysis

Since the reliability measures are far below 0.70 commonly considered Cronbach's Alpha, we have decided to disregard the possibility of aggregating measures. we then use multiple regression analysis, including a moderated regression and mediation regression. Also because of the lack of theory and meaningful arguments that would support aggregating the items that were loaded on the factors. There is also another reason to believe it is not appropriate to aggregate these items together, where some countries do have high level of openness and low level of regulation quality. Also some other countries such as East European countries are part of the European Union where they are required to have specific levels of openness towards other members but still lack the quality of regulations, as well as stability and absence of violence. Aggregating the measures would make the findings biased.

We first use OLS regression to test for the main effect. Following Baron and Kenny (1986), we test for the moderating effect of regulation quality by entering the independent variable, the moderator, and then the interaction effect. In model 1 the independent variable is entered, the moderator is entered in model 4, and finally the interaction was entered in model 5. We utilize Preacher and Hayes approach, as well as Baron and Kenny approach for testing the moderating effect hypothesis

Table 1. Descriptive statistics for the variables

\begin{tabular}{|c|c|c|c|c|c|c|c|c|c|c|c|}
\hline \multicolumn{12}{|c|}{ Descriptive Statistics } \\
\hline & $\mathrm{N}$ & Range & Minimum & Maximum & Mean & Std. Deviation & Variance & \multicolumn{2}{|c|}{ Skewness } & \multicolumn{2}{|c|}{ Kurtosis } \\
\hline & Statistic & Statistic & Statistic & Statistic & Statistic & Statistic & Statistic & Statistic & Std. Error & Statistic & Std. Error \\
\hline tradeopenness & & & & & & & & & & & \\
\hline $\begin{array}{l}1-6 \text { ( } 1 \text { very week } \\
\text { and } 6 \text { most open }\end{array}$ & 59 & 3.7 & 1 & 4.7 & 2.9373 & 1.28813 & 1.659 & -0.402 & 0.311 & -1.33 & 0.613 \\
\hline contrlcorruption & 59 & 3.86 & -1.46 & 2.39 & 0.2678 & 1.1218 & 1.258 & 0.505 & 0.311 & -1.003 & 0.613 \\
\hline Politicstability & 59 & 4.08 & -2.68 & 1.4 & -0.0138 & 0.98417 & 0.969 & -0.693 & 0.311 & -0.122 & 0.613 \\
\hline regulatquality & 59 & 4.13 & -2.24 & 1.89 & 0.3106 & 1.0172 & 1.035 & -0.16 & 0.311 & -0.847 & 0.613 \\
\hline $\operatorname{lnfdi}$ & 59 & 10.36 & 15.74 & 26.11 & 21.5412 & 2.14966 & 4.621 & -0.483 & 0.311 & 0.152 & 0.613 \\
\hline Valid N (listwise) & 59 & & & & & & & & & & \\
\hline
\end{tabular}




\section{Results}

Table 2. OLS regression analysis

\begin{tabular}{lccccccccccc}
\hline Variables & \multicolumn{2}{c}{ Model1 } & \multicolumn{2}{c}{ Model } & \multicolumn{2}{c}{ Model3 } & \multicolumn{2}{c}{ Model4 } & \multicolumn{2}{c}{ Model5 } \\
\hline & $\boldsymbol{b}$ & $\boldsymbol{s . e}$ & $\boldsymbol{b}$ & $\boldsymbol{s . e}$ & $\boldsymbol{b}$ & $\boldsymbol{s . e}$ & $\boldsymbol{b}$ & $\boldsymbol{s . e}$ & $\boldsymbol{b}$ & $\boldsymbol{s} . \boldsymbol{e}$ \\
constant & $18.3^{*}$ & 0.532 & $18.23^{*}$ & 0.614 & $18.288^{*}$ & 0.672 & $18.80^{*}$ & 0.703 & $19.37^{*}$ & 0.764 \\
Tradeopen & $1.127^{*}$ & 0.19 & $1.127^{*}$ & 0.195 & $1.1^{*}$ & 0.233 & $0.879^{*}$ & 0.252 & $0.798^{*}$ & 0.252 \\
politstab & & & -0.065 & 0.256 & -0.119 & 0.355 & -0.102 & 0.346 & -0.197 & 0.344 \\
corruption & & & & & 0.08 & 0.367 & -0.412 & 0.434 & 0.03 & 0.496 \\
regulation & & & & & & & $0.86^{*}$ & 0.428 & $1.917^{*}$ & 0.74 \\
Interaction & & & & & & & & & $-0.415^{* *}$ & 0.239 \\
F-Stat & $43.96^{*}$ & & $21.65^{*}$ & & $14.20^{*}$ & & $12.24^{*}$ & & $10.76^{*}$ & \\
$\mathbf{R}^{2}$ & 0.435 & & 0.436 & & 0.437 & & 0.476 & & 0.504 & \\
$\Delta \mathbf{R}^{2}$ & & & 0.001 & & 0 & & $0.039^{*}$ & & $0.028^{* *}$ & \\
\hline
\end{tabular}

Note. $* \mathrm{P}<0.05 * * \mathrm{P}<0.10$.

Table 1 displays descriptive statistics for the variables. Some of the variables included in the descriptive statistics were not used as we did not intend to study their effect, however, it will be our intention to use all the variables that we collected data for in future studies. Missing data were dealt with by SPSS using the listwise method.

As shown in table 2, the results show that trade openness does explain $43.5 \%$ of the variation in FDI Inflows across countries. The OLS regression analysis shows a positive coefficient of the variable trade openness in all models, and also statistically significant in all models. Model 1 shows the main effect of trade openness on the FDI inflows ( $\mathrm{t}=6.63, \mathrm{P}=0.000)$. The coefficient is positive and significant $(\mathrm{P}<0.05)$, providing support for hypothesis 1 . This is also consistent with previous research that suggest a positive relationship between trade openness and FDI inflows (Blonigen \& Piger, 2014; Liargovas \& Skandalis, 2012; Shirazi et al., 2010).

In Model 2, we entered the variable political stability. The results show insignificant effect of the variable stability/absence of violence $(\mathrm{t}=-0.256, \mathrm{P}=0.7)$. Interestingly, though the results were statistically insignificant for the variable stability and violence. Also, the $\Delta \mathrm{R}^{2}$ was not statistically significant nor it changed significantly $\left(\mathrm{R}^{2}=43.6\right)$ with only $0.1 \%$ change. Therefore, hypothesis 2 is not supported.

In model 3, we entered the variable corruption to test for hypothesis 3 . The results show that the effect of corruption is positive, meaning that the more effective the government in controlling corruption, the more the FDI inflows. However, the effect was statistically insignificant $(\mathrm{t}=0.219, \mathrm{P}=0.8)$. The variable was still statistically insignificant in model 3, 4, and 5. The coefficient has a positive effect only in model 3 and 5 , and negative effect in model 4 which would have supported the money-grease argument.

In model 4 we enter the variable regulation quality to test for hypothesis 4 . The results show support for hypothesis 4 as the coefficient is positive and statistically significant at the $10 \%$ level $(\mathrm{t}=2.01, \mathrm{P}=0.05)$. Which indicates a positive effect for the quality of regulation in any country on the flows of foreign direct investment.

In model 5, we enter the interaction term between regulation quality and the trade openness. We argue that the better the regulations a country have, the larger the effect of trade openness on foreign direct investment. That is, the quality of regulation will positively moderate the relationship between trade openness and foreign direct investment inflows. Our argument is that we would find countries where they are open to trade, politically stable, and have some other attractive features. Yet, if they would not have a good regulation in place that would help foreign investors to come and invest in their countries, the effect of openness would not be the same as if the quality of regulations were higher.

Interestingly, the interaction term coefficient after entering all the other variables in model 5 was negative and significant at the $10 \%$ level $(\mathrm{t}=-1.8, \mathrm{P}=0.08)$. This is contrary to what we expected, in part it may be due to the measurement scale used for the variables under consideration which we obtained from the database of the World Bank and for practical reasons and the unavailability of a uniform measures in the economic and international business literature. It also may be the case that regulation quality doesn't necessarily play a role as long as some other features are available in a country such as resources, low labor costs, and some other business-related variables that foreign investors and MNCs would see as advantageous and disregard the regulation quality if these other variables can minimize the costs to the extent at which their profit are to be larger.

Preacher and Hayes approach for testing the moderation effect of regulation quality. 
Table 3. Preacher and Hayes-Model 1 (moderation effect of regulation quality)

\begin{tabular}{lllllll}
\hline Predictors & $\boldsymbol{b}$ & s.e & t-stat & $\boldsymbol{P}$ & LCI & UCI \\
\hline Constant & $22^{*}$ & 0.2953 & 74.3 & 0 & 21.36 & 22.55 \\
Regqualit & $0.616^{* *}$ & 0.371 & 1.66 & 0.1 & -0.12 & 1.35 \\
Tradeopen & $0.6537^{*}$ & 0.2931 & 2.23 & 0.03 & 0.06 & 1.2 \\
Interaction & $-0.434^{*}$ & 0.1902 & -2.28 & 0.026 & -0.81 & -0.05 \\
$\boldsymbol{R}^{2}$ & 0.4998 & & & & & \\
$\boldsymbol{F}$ & $16.21(3,55)^{*}$ & & & & & \\
$\boldsymbol{P}$ & 0 & & & & & \\
\hline
\end{tabular}

Note. $* \mathrm{P}<0.05, * * \mathrm{P}<0.10$.

The results from Preacher and Hayes model 1 (Moderation) yielded mostly similar results to the OLS regression. The difference was in the statistical significance where Baron and Kenny approach yielded a P-value of 0.08 , whereas using Preacher and Hayes macro process yielded a P-value close to 10 with almost $2 \%$ difference. The interaction term however, was still statistically significant and negative indicating that the more advanced the regulations, the lower the positive effect of regulation quality on the FDI inflows. This could however, be due to several reasons including the sample size in the study, endogeneity, omitted variables such as specific regulations such as Tax, and geographical locations, as well as the distances from the country to central markets in the world.

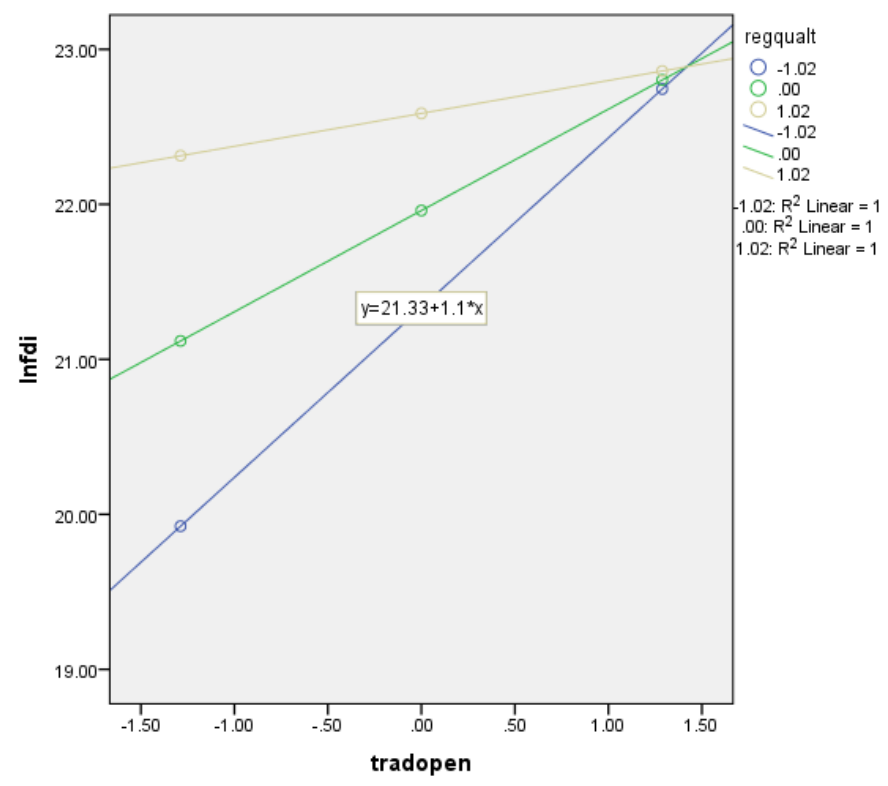

Figure 2. Moderation effect of regulation quality

\subsection{A Model for the Under-Developed Countries}

Table 4. OLS regression-under-developed countries

\begin{tabular}{|c|c|c|c|c|c|c|c|c|c|c|}
\hline \multirow[t]{2}{*}{ Variables } & \multicolumn{2}{|c|}{ Model1 } & \multicolumn{2}{|c|}{ Model2 } & \multicolumn{2}{|c|}{ Model } & \multicolumn{2}{|c|}{ Model4 } & \multicolumn{2}{|c|}{ Model5 } \\
\hline & $b$ & s.e & $b$ & s.e & $b$ & s.e & $b$ & s.e & $b$ & s.e \\
\hline Constant & $18.8^{*}$ & 0.64 & $18.38^{*}$ & 0.699 & $17.966^{*}$ & 0.806 & $18.31 *$ & 0.753 & 18.37 & 0.926 \\
\hline Tradeopen & $1.192 *$ & 0.253 & $1.161 *$ & 0.258 & $1.298^{*}$ & 0.289 & $1.18^{*}$ & 0.27 & $1.153^{*}$ & 0.315 \\
\hline Politstab & & & 0.242 & 0.326 & 0.512 & 0.416 & 0.644 & 0.386 & 0.623 & 0.43 \\
\hline corruption & & & & & -0.611 & 0.588 & $-1.491 *$ & 0.641 & $-1.449 *$ & 0.74 \\
\hline regulation & & & & & & & $1.211^{*}$ & 0.474 & 1.306 & 0.926 \\
\hline Interaction & & & & & & & & & -0.044 & 0.367 \\
\hline F-Stat & 22.17 & & 11.209 & & 7.851 & & 8.6 & & 6.6 & \\
\hline$R^{2}$ & 0.409 & & 0.42 & & 0.44 & & 0.543 & & 0.543 & \\
\hline$\Delta \boldsymbol{R}^{2}$ & & & 0.01 & & 0.02 & & 0.103 & & 0 & \\
\hline
\end{tabular}


After excluding the developed and advanced countries which were 16 countries, the results of the OLS regression are reported in Table 4.

Model 1 shows that trade openness has a statistically significant positive effect ( $\mathrm{t}=4.7, \mathrm{P}=0.000)$. Indicating that for these under-developed countries that are more open for trade, it is expected that they will have more FDI inflows which supports hypothesis 1 . The model explains $40.9 \%$ of the variance.

In model 2, we enter the variable political stability. The results show positive relationship between FDI inflows and stability, however, it is statistically insignificant $(\mathrm{t}=.74, \mathrm{P}=0.463)$. The model explains $42 \%$ of the variance in FDI inflows between countries, with a $\Delta \mathrm{R}^{2}=1.1 \%$ which is not much addition. This indicates that stability doesn't actually account for much in the variance by itself.

Model 3, we enter the variable control of corruption. The negative sign provides support for the grease-money argument that corruption has a positive effect on FDI inflows, and that for countries with lower levels of control of corruption, they are likely to receive more FDI. However, the variable in model 3 is statistically insignificant $(\mathrm{t}=-1.03, \mathrm{P}=0.30)$. And was only significant when entered in model 4 alongside the variable regulation quality $(\mathrm{t}=$ $-2.33, \mathrm{P}=0.02$ ). Model 3 accounts for $44 \%$ of the variation, indicating a $\Delta \mathrm{R}^{2}=2 \%$ which is still not a large improvement in the model.

In model 4 , we enter the variable regulation quality. The results yield a significant and positive effect of regulation quality on the amount of FDI inflows $(\mathrm{t}=2.56, \mathrm{P}=0.01)$. Model 4 explains $54 \%$ of the variance with $\Delta \mathrm{R}^{2}=10 \%$ which is a noticeable increase in the variance explained when we added the variable regulation quality, indicating a visible effect of regulation quality on the amount of FDI inflows into countries. This is actually very reasonable as investors would like to ensure that their investments are secured and that they will have rewarding incentives by investing in such countries with good regulations, as well as fair treatment.

Lastly, we enter the interaction term. The results show that the interaction term is statistically insignificant $(-0.12$, $\mathrm{P}=0.9$ ).

Overall, the results provide support for hypothesis 1, hypothesis 4. Partial support for the corruption hypothesis was found. Indicating that these underdeveloped countries may in fact benefit from corruption somehow. No moderation effect was found for regulation quality on the relationship between openness for trade and FDI inflows, which indicates that these countries lack the regulatory quality and need to work harder to compete for FDI.

\section{Conclusions and Discussion}

The purpose of this study is to assess whether and to what extent the selected variables (Trade Openness, Political Stability and Violence, Control of Corruption, and Regulation Quality) influence the FDI inflows into the country. In addition, we also examine the moderating effect of regulation quality on the relationship between trade openness and FDI inflows. The study uses set of indices provided by the World Bank in cooperation with several well-known economists. The data for this study was selected for the year 2012 for practical reasons and availability of data for the most part.

The results noticeably indicate that trade openness accounts for the most variation in FDI inflows across countries. It is one of the most important determinants of FDI inflows into countries. It was expected that trade openness would be positively associated with greater amount of foreign investment flows into countries. However, political stability and absence of violence did not yield significant effect in the model developed from OLS regression analysis which could be due to the fact that its effect might be captured by other variables, either included in the model such as regulation quality and openness, or variables that we did not include in the model due to availability of measures or consensus upon the measurements used. We did try to include the HDI (Human Development Index) in our model. The HDI index assumed to capture the education level, the health and well-being of a nation, and the GDP for countries. It is a composite index measuring average achievement in three basic dimensions of human development - a long and healthy life, knowledge and a decent standard of living. The variable did not yield any significant effect in any of the models, nor did it improve the goodness of fit for the selected models. Besides, it was not our intention to study the relationship between the HDI and the FDI inflows as the major purpose of our study is to see whether the selected set of scaled variables can significantly explain the variation in FDI inflows between countries, therefore, the HDI index was not used in the final analysis. These findings are consistent with what Globerman and Shapiro (2002) reported with respect to human capital (education and health) and environmental sustainability. The authors reported that the results were less reliably estimated owing to problems of multicollinearity and causality.

The results of our analysis show also that neither corruption nor political stability are major and significant 
determinants of the FDI inflows. As explained previously in this paper, this could be due to several reasons including omitted variables, measurement issues, and endogeneity.

The results provide support for the regulatory effect argument, and that regulation quality does matter and have, to some extent, significant effect on the FDI inflows. The moderating effect, however, show the opposite to what Our expected. It shows that regulation quality may play negative role on the relationship between openness and FDI. That is, countries with high levels of openness and low regulation quality may have better chances of receiving larger amount of FDI inflows, which could be due to the fact that MNCs may prefer to invest in countries where regulations are not well-established to benefit from regulations gaps and flaws. Also, could be due to the fact that some open-for-trade countries have very low labor cost, ample resources, and other attractive features that make them desirable for MNCs despite their low-quality regulations.

\section{Limitations and Future Directions}

As mentioned previously, we would have loved to use all the data available that we collected from the World Bank, OECD, and United Nation data. But after running two rounds of factor analysis, there were no meaningful way to aggregate some uniform measures to construct more comprehensive variables. For practical reasons, namely the availability of data and limited number of measures used in the literature, we use these measures despite the fact that they are only estimates, small scale, and not as much practical as they would have been if collected based on precise measures for all countries. This research has several limitations. First, the data as we mentioned are mostly estimate and they do not reflect precise measurement of the constructs that are intended to be measured. Second. Despite the fact that these variables capture significant amount of the variance (50\%), there could be more important variables and determinants of the FDI inflows, such as the richness of resources, the labor laws, labor costs, level of technological advancement for countries, and many other important variables that would contribute to the variation across countries with respect to the FDI inflows. In addition, the country geographical classification and level of development as our study does not differentiate between advanced, developing, or under-developed countries. Our intention was to develop a general model that would explain variance in FDI inflows regardless to the level of development a country has reached so far. Third, the single source used for this data is problematic, as much as we would have loved to obtain data from several sources, but the availability of data, as well as the ununiformed measures used by the economic and international business scholars have limited our ability to use more reliable measures from several sources. Fourth, the study only addresses the influence of country factors on FDI inflows, and does not take into account the FDI outflows. While it is widely argued that FDI inflows and outflows are somehow influenced by each other, it would have been a more solid study if we were to include the FDI outflows. In the future, we aim to include the outflows, as well as some other important elements such as the country's R\&D spending, Human Capital index, and some other relative factors.

Future research could further our understanding by utilizing more precise measures; measures that capture each country's specific advantages vs disadvantages. Also, future research could study specific regional trade zones such as NAFTA and EU and test the applicability of previous findings and perspectives on such trade bodies. Future research could also study the countries that recently joined the European Union, especially from East Europe and see what has been hindering such countries from being as attractive as their partners in the Union. Future research could also study the effect of R\&D promotion and human capital specific features and its effect on the country's attractiveness for FDI. In addition, research could also enhance our understanding for the role played by government officials, investment committees, expatriates, and migrants and their roles of attracting FDI into their countries.

\section{References}

Allen, M. M. C., \& Aldred, M. L. (2013). Business regulation, inward foreign direct investment, and economic growth in the new european union member states. Critical Perspectives on International Business, 9(3), 301-321. http://dx.doi.org/10.1108/17422041311330431

Ardiyanto, F. (2012). Foreign direct investment and corruption.

Asiedu, E., \& Lien, D. (2011). Democracy, foreign direct investment and natural resources. Journal of International Economics, 84(1), 99-111. http://dx.doi.org/10.1016/j.jinteco.2010.12.001

Bellos, S., \& Subasat, T. (2012). Corruption and foreign direct investment: A panel gravity model approach. Bulletin of Economic Research, 64(4), 565-574.

Bénassy-Quére, A., Coupet, M., \& Mayer, T. (2007). Institutional determinants of foreign direct investment. The World Economy, 30(5), 764-782. http://dx.doi.org/10.1111/j.1467-9701.2007.01022.x 
Blonigen, B. A., \& Piger, J. (2014). Determinants of foreign direct investment. The Canadian Journal of Economics, 47(3), 775-812. http://dx.doi.org/10.1111/caje.12091

Constant, Z. S. (2010). The relationship between foreign direct investment, trade openness and growth in cote D'Ivoire. International Journal of Business and Management, $5(7), 99$. http://dx.doi.org/10.5539/ijbm.v5n7p99

Corcoran, A., \& Gillanders, R. (2015). Foreign direct investment and the ease of doing business. Review of World Economics, 151(1), 103-126. http://dx.doi.org/10.1007/s10290-014-0194-5

Cuadros, A., Alguacil, M., \& Orts, V. (2004). Openness and growth: Re-examining foreign direct investment, trade and output linkages in latin america. The Journal of Development Studies, 40(4), 167-192. http://dx.doi.org/10.1080/00220380410001673238

Globerman, S., \& Shapiro, D. (2002). Global foreign direct investment flows: The role of governance infrastructure. World Development, 30(11), 1899-1919. http://dx.doi.org/10.1016/S0305-750X(02)00110-9

Globerman, S., \& Shapiro, D. (2003). Governance infrastructure and US foreign direct investment. Journal of International Business Studies, 34(1), 19-39. http://dx.doi.org/10.1057/palgrave.jibs.8400001

Globerman, S., \& Shapiro, D. M. (1999). The impact of government policies on foreign direct investment: The canadian experience. Journal of International Business Studies, 30(3), 513-532. http://dx.doi.org/10.1057/palgrave.jibs.8490081

Habib, M., \& Zurawicki, L. (2002). Corruption and foreign direct investment. Journal of International Business Studies, 33(2), 291-307. http://dx.doi.org/10.1057/palgrave.jibs.8491017

Hall, R. E., \& Jones, C. I. (1999). Why do some countries produce so much more output per worker than others? The Quarterly Journal of Economics, 114(1), 83-116. http://dx.doi.org/10.1162/003355399555954

Herzer, D. (2012). How does foreign direct investment really affect developing countries' growth? Review of International Economics, 20(2), 396-414. http://dx.doi.org/10.1111/j.1467-9396.2012.01029.x

Humphrey, J. (1998). Trust and inter-firm relations in developing and transition economies. The Journal of Development Studies, 34(4), 32-61. http://dx.doi.org/10.1080/00220389808422528

Javorcik, B. S., Özden, Ç, Spatareanu, M., \& Neagu, C. (2011). Migrant networks and foreign direct investment. Journal of Development Economics, 94(2), 231-241. http://dx.doi.org/10.1016/j.jdeveco.2010.01.012

Kaufmann, D., \& Kraay, A. (2002). Growth without governance. World Bank Policy Research Working Paper, (2928).

Kaufmann, D., \& Wei, S. (1999). Does "grease money" speed up the wheels of commerce? National Bureau of Economic Research.

Kaufmann, D., Aart, K., \& Massimo, M. (2010). The Worldwide Governance Indicators: Methodology and Analytical Issues. World Bank Policy Research.

Khawar, M. (2005). Foreign direct investment and economic growth: A cross-country analysis. Global Economy Journal, 5(1), 8. http://dx.doi.org/10.2202/1524-5861.1057

Kim, D., Lin, S., \& Suen, Y. (2013). Investment, trade openness and foreign direct investment: Social capability matters. International Review of Economics \& Finance, 26, 56-69. http://dx.doi.org/10.1016/j.iref.2012.08.008

Kim, H. (2010). Political stability and foreign direct investment. International Journal of Economics and Finance, 2(3), 59-71. doi:10.5539/ijef.v2n3p59

Kobrin, S. J. (1976). The environmental determinants of foreign direct manufacturing investment: An ex post empirical analysis. Journal of International Business Studies, 7(2), 29-42. http://dx.doi.org/10.1057/palgrave.jibs.8490699

Lee, J. (2005). Cross-country evidence on the effectiveness of foreign investment policies. The International Trade Journal, 19(4), 363-389. http://dx.doi.org/10.1080/08853900500290772

Liargovas, P. G., \& Skandalis, K. S. (2012). Foreign direct investment and trade openness: The case of developing economies. Social Indicators Research, 106(2), 323-331. http://dx.doi.org/10.1007/s11205-011-9806-9

Melo, L., \& Quinn, M. A. (2015). Oil, Foreign Direct Investment and Corruption. The International Journal of 
Business and Finance Research, 9(1), 33.

Méon, P., \& Weill, L. (2010). Is corruption an efficient grease? World Development, 38(3), $244-259$. http://dx.doi.org/10.1016/j.worlddev.2009.06.004

Quazi, R. M. (2014). Corruption And Foreign Direct Investment In East Asia And South Asia: An Econometric Study. International Journal of Economics and Financial Issues, 4(2), 231-242.

Ram, R., \& Zhang, K. (2002). Foreign direct investment and economic growth: Evidence from Cross - Country data for the 1990s. Economic Development and Cultural Change, 51(1), 205-215. http://dx.doi.org/10.1086/345453

Russett, B. M. (1968). Economic theories of international politics. Chicago: Markham Pub. Co.

Sahoo, P., Nataraj, G., Dash, R. K., \& Ebooks Corporation. (2014). Foreign direct investment in south asia: Policy, impact, determinants and challenges. New Delhi: Springer. http://dx.doi.org/10.1007/978-81-322-1536-3

Shirazi, F., Gholami, R., \& Higón, D. A. (2010). Do foreign direct investment (FDI) and trade openness explain the disparity in ICT diffusion between Asia-Pacific and the Islamic middle eastern countries? Journal of Global Information Management, 18(3), 59-81. http://dx.doi.org/10.4018/jgim.2010070103

Siddharthan, N. S., \& Lakhera, M. L. (2005). Foreign direct investment and location advantages: Japanese perceptions of india compared to china and ASEAN. Journal of International and Area Studies, 12(1), 99-110.

Siegel, J. I., Licht, A. N., \& Schwartz, S. H. (2013). Egalitarianism, cultural distance, and foreign direct investment: A new approach. Organization Science, 24(4), 1174-1194. http://dx.doi.org/10.1287/orsc.1120.0776

Torriti, J., \& Ikpe, E. (2015). Administrative costs of regulation and foreign direct investment: The standard cost model in non-OECD countries. Review of World Economics, 151(1), 127-144. http://dx.doi.org/10.1007/s10290-014-0200-y

Wheeler, D., \& Mody, A. (1992). International investment location decisions. Journal of International Economics, 33(1), 57-76. http://dx.doi.org/10.1016/0022-1996(92)90050-T

Wu, J., Li, S., \& Selover, D. D. (2012). Foreign direct investment vs. foreign portfolio investment. Management International Review, 52(5), 643. http://dx.doi.org/10.1007/s11575-011-0121-0

Yeaple, S. R. (2003). The complex integration strategies of multinationals and cross country dependencies in the structure of foreign direct investment. Journal of International Economics, 60(2), 293-314. http://dx.doi.org/10.1016/S0022-1996(02)00051-X

Zurawicki, L., \& Habib, M. (2010). Corruption and foreign direct investment: What have we learned? International Business and Economics Research Journal, 9(7), 1-9.

\section{Copyrights}

Copyright for this article is retained by the author(s), with first publication rights granted to the journal.

This is an open-access article distributed under the terms and conditions of the Creative Commons Attribution license (http://creativecommons.org/licenses/by/3.0/). 